\title{
E-learning rendszer az agrárképzésben
}

Péter Lengyel ${ }^{1}$

\section{N F O}

Received 12 April 2010

Accepted 19 May 2010

Available on-line 31 May 2010

Responsible Editor: K. Rajkai

\section{Keywords:}

Moodle, e-learning, LMS

\section{N F O}

Beérkezés 2010 Április 12. Elfogadás 2010 Május 19.

On-line elérés 2010 Május 31.

Felelős szerkesztő: Rajkai K

Kulcsszavak:

Moodle, e-learning, LMS

\section{$\underline{\text { ABSTRACT }}$}

We use Moodle at the University of Debrecen, Faculty of Applied Economics and Rural Development since November 2007. Moodle is an open source Learning Management System. Learning Management System (or LMS) is a software package, that enables the management and delivery of learning content and resources to students. Most LMS systems are web-based to facilitate "anytime, anywhere" access to learning content and administration. LMS tracks student progress in a course and indicates completions. At the least, learning management systems track individual student progress, record scores of quizzes and tests within an online learning program, and track course completions. Moodle has more and more function at our Department in education. Our aim is to develop such a learning system, which is an integral part of educational process. This paper shows the architecture and function of this system, and the experiences of our faculty.

\section{Ö S S Z E F O G L A L Ó}

A Debreceni Egyetem Gazdálkodástudományi és Vidékfejlesztési Karán 2007 november óta használjuk a Moodle-t, mely egy nyílt forráskódú LMS (Learning Management System) rendszer, azaz tanulásirányítási rendszer. A tanulásirányítási rendszerek feladata, hogy azonosítsa a felhasználókat, és szerepkörük, jogosultságaik szerint a megfelelő kurzusokkal összerendelje őket. Az LMS szerverek a felhasználók tevékenységeit, a tanulás szempontjából fontos adatokat naplózzák, s ebből a későbbiekben statisztikák generálhatók. Ezek az adatok egyrészt a tanulók haladásával kapcsolatosan szolgáltatnak fontos információkat, másrészt a tananyag hatékonysága is kideríthető belőlük. A karunkon bevezetésre került rendszer egyre nagyobb szerepet kap az oktatásban. Célunk egy olyan oktatási rendszer kialakítása, amely ténylegesen szerves részét képezi az oktatási folyamatoknak. Ez a cikk bemutatja a rendszer felépítését, müködését és az eddigi kari szintü tapasztalatokat.

\section{Bevezetés}

A Debreceni Egyetem Gazdálkodástudományi és Vidékfejlesztési Kara (DE-GVK) részt vett egy nemzetközi e-learning projektben (NODES), melynek célja a multimédia technológiák alkalmazásának a támogatása a felnőttképzésben és az élethosszig tartó tanulásban. Ennek keretében 2007 januárjában kialakításra került egy e-learning hálózat, melynek részét alkotja a Moodle elearning rendszer (Burriel, 2007). A Moodle egy nyílt forráskódú Learning Management System (LMS), magyarul tanulásirányítási rendszer (Lengyel et al., 2007).

A Learning Management System feladata, hogy azonosítsa, nyilvántartsa, kövesse az oktatási folyamatban résztvevő felhasználókat és szerepkörük, jogosultságaik szerint a megfelelő kurzusokkal rendelje őket össze. Az LMS szerverek a felhasználók tevékenységeit, a tanulás szempontjából fontos adatokat naplózzák, s ebből a későbbiekben statisztikák generálhatók. Ezek az adatok egyrészt a tanulók haladásával kapcsolatosan szolgáltatnak fontos információkat, másrészt a tananyag hatékonysága is kideríthető belölük (Gaceu et al., 2009).

A rendszerben közreadott, gondosan elkészített tananyagok és a hallgatóknak a tanítás-tanulási folyamatban való aktívabb közremúködése, részvétele biztosíthatja annak lehetőségét, hogy a tanulási folyamatot támogató rendszer segítségével az oktatás minősége javuljon és hatékonysága növekedjen.

\footnotetext{
${ }^{1}$ Péter Lengyel

University of Debrecen, 4032 Debrecen, Böszörményi út. 138, Hungary

lengyel@agr.unideb.hu
} 
A Moodle, mint minden keretrendszer kitágítja a tanítás terét és idejét: a tanulók bármikor hozzáférhetnek a digitális forrásokhoz és feladatokhoz, kommunikálhatnak egymással és tanáraikkal a sikeres megoldás, az eredményes tanulás érdekében. A tanulásban és a feladatmegoldásban is egyre inkább a közös munkára, a kooperációra kell a hangsúlyt helyezni. A hatékony tanulás folyamatában az együttmüködés nem tiltandó, hanem különböző eszközökkel és módszerekkel támogatandó munkaforma (Wagner, 2008).

\section{A Moodle keretrendszer jellemzői}

A Moodle (Modular Object-Oriented Dynamic Learning Environment) egy nyílt forráskódú ingyenes, open source (szabad forráskódú), intézményre és személyre szabható keretrendszer. 1999ben, Ausztráliában került kifejlesztésre. Ma a legelterjedtebb LMS rendszer a világon: jelenleg 197 országban több mint 35 ezer regisztrált változatban müködik, 15 millió feletti regisztrált felhasználóval (forrás: www.moodle.org). A valós felhasználói szám ennél is nagyobb, havonta átlagosan 40 ezer alkalommal töltik le a szoftvert. Jelenleg 74 nyelvi csomag tölthető le. A rendszer hivatalos weboldala a http://www.moodle.org, ahonnan letölthetjük a legfrissebb verziót, a nyelvi elemeket, és megismerhetjük a Moodle felhasználók széles táborát.

A Moodle keretrendszer segítségével kiépített LMS interaktív és virtuális tanulási környezetet biztosít, amely lehetővé teszi tananyagok elhelyezését és elérését, kurzusok szervezését, tesztek készítését. A kurzusok résztvevői fórumokon és e-mail formájában is kommunikálhatnak egymással a tanulás érdekében, tanulási eszközként felhasználva e módokat.

\subsection{Tananyagelemek a Moodle rendszerben}

A Moodle-ban a tananyagok elhelyezése a képzési struktúra definiálásával kezdődik. A Moodle a kurzus lebonyolítására vonatkozóan három kategóriát állít fel:

- A fórum formátumban a Moodle szerepe a képzésben résztvevők „laza” kapcsolattartására szolgál, de a teljes tartalompaletta igénybe vehető.

- A tematikus formátumban a tantárgyban meglévő témaköröknek önálló tartalmi modulokat jelölhetünk ki.

- A heti formátumban hetekre bontva határozhatjuk meg a tartalmi modulokat.

A tananyag feltöltése során a tanárnak lehetősége van helyben elkészíteni az adott témához tartozó tananyagelemeket. Készíthet külső HTML hivatkozásokat, illetve feltölthet állományokat. A megfelelő címkék, azaz a tananyagelemek közötti összekötő szöveg elhelyezésével és a tananyagelemek logikus elhelyezésével az egész órát kitöltő élvezetes, tanulói aktivitásra épülő munkát lehet tervezni, akár differenciáltan is. A tanulói tevékenységek ezután már saját tempóban folyhatnak, a tanár pedig ott segít, ahol erre szükség van.

A Moodle további nagy előnye, hogy nyomon követhető a tanulók aktivitása, valamint a rendszerben készített interaktív feladatok megoldásának helyessége. Az interaktív feladatlapok biztosítása fokozza a tanulók motivációját, tudják, hogy a Moodle rögzíti a teljesítményüket, szigorúan betartatja az időkorlátokat. A diákok általában szeretnek megfelelni a követelményeknek, szívesen tesztelik tudásukat akár többször is egy órán. Fontos számukra, hogy az elvégzett feladatok helyességéről azonnal kapnak visszajelzést, ez pozitívan befolyásolja munkakedvüket és az egészséges versenyszellemet is (Herdon és Várallyai, 2006).

Az e-Learning tananyagok a szabványos (IMS, SCORM) tananyagcsomagokkal is előállíthatók, melyek közöl az eXe Editor, és a Reload Editor az említésre méltó. A Learning Design külön hangsúly kap a tananyag-elöállításon belül, mivel ez a módszer a teljes oktatási folyamatot képes önmagában modellezni (Tóth et al., 2008).

A tananyagok nyilvántartására több példa is született. A LOR (learning object repository): Metatagekkel ellátott tananyagelemeket tartalmazó tároló. Ilyen tárolókat hoztak létre már több európai projekt keretében (Manouselisa et al., 2009). 


\subsection{A Moodle rendszer moduljai}

A Moodle rendszerhez több mint 200 modul és blokk érhető el kiegészítő eszközként a moodle.org oldalon. Ezek nagy része szintén szabad forráskódú, tehát ingyenesen integrálható a Moodle-ba. Az eszközök között több multimédiás modul, kommunikációs eszköz, tananyag-, és tesztszerkesztő eszköz található. A Moodle hatékony alkalmazása érdekében nagy hangsúlyt fektetünk ezen eszközök tesztelésére, illetve használatára. Az alábbiakban felsorolok olyan multimédiás eszközöket, melyek modulként vagy blokként épülnek be a Moodle rendszerbe.

- Covcell Audio-/Video Conferencing Tool: Audio/Video Konferencia eszköz

- Inwicast Mediacenter: Könnyen közzé tehetjük, kezelhetjük és megoszthatjuk audio és video anyagainkat különböző formátumokban (flv, mp3, mp4, wmv, mov, stb.).

- Flash Video: Fő célja, hogy megjegyzésekkel és mellékletekkel összefüzött videó tartalmat osszon meg a hallgatókkal.

- Audio Recorder: Mp3 formátumú audio állományt lehet létrehozni.

- Audioconference modul: Kifejezetten konferenciabeszélgetést támogató modul.

- AutoView Presenter: Prezentáció diáival szinkronizálva, videó anyagokat közölhetünk.

Ezen túl nagy szerepet kap egy olyan eszköz, mely a tesztek készítését könnyíti meg: egy Word sablon, melynek segítségével egyszerüen és gyorsan létrehozhatjuk a dokumentumban már létező tesztjeinkből azt a GIFT formátumú anyagot, amit a Moodle-be be tudunk importálni (Herdon, Lengyel, 2008).

\section{A Moodle rendszer használata az agrár-felsőoktatásban}

Információim szerint a hazai agrár-felsőoktatásban igen elterjedt az e-learning technológia használata és több intézmény döntött a Moodle keretrendszer alkalmazása mellett. Ezek közül a következő alkalmazásokat tartom fontosnak megemlíteni:

- A Szegedi Tudományegyetem Mezőgazdaságtudományi Kara a Moodle e-leaning rendszert használja, mely keretrendszeren belül több kurzus is található az Ökonómiai ismeretek, Állattenyésztés-Állatélettan és Alternatív agrárium témakörökben. (http://kt20.mfk.uszeged.hu/moodle/).

- Szent István Egyetem e-learning portálja szintén a Moodle rendszeren alapul. Itt található a Mezőgazdasági- és Környezettudományi Kar kurzusai, többek között állatélettan, termelésélettan, környezetélettan. (http://elearning.szie.hu/course/category.php?id=7).

- Ugyanúgy a Moodle rndszert használja a Corvinus Egyetem Kertészettudományi Kara

A Debreceni Egyetem Gazdálkodástudományi és Vidékfejlesztési Karán alkalmazott rendszer (http://nodes.agr.unideb.hu/eportal) bemutatása képezi a jelen tanulmány fö feladatát.

Közel egy éves tesztelést, tapasztalatszerzési és próbaüzemelési időszakot követően 2007 novemberében vezettük be a Moodle keretrendszert. Az elmúlt két év során szerzett alkalmazási tapasztalatok azt mutatják, hogy mind az órai munkához, mind az otthoni felkészüléshez jelentőst támogatást tudunk nyújtani az oktatáspedagógiailag korrekten létrehozott és feltöltött anyagokkal. Ehhez szorosan kapcsolódik az elektronikus tananyagfejlesztés, mely az uniós HEFOP pályázati projekt keretein belül oktatóink részvételével több tantárgy esetében már részben megvalósult.

Nagy hangsúlyt fektetünk a rendszer számonkérésre történő használatára, mely tesztek, illetve feladatok alkalmazásával történik. A Moodle-ban számos tesztkérdés típus között válogathatunk, ennek megfelelően színes, változatos teszteket hozhatunk létre (Lengyel és Herdon, 2008).

A kari oktatók részére szervezett kurzusokon ismertetjük a rendszer müködését, használhatóságát és mutatjuk be a rendszerben rejlő lehetőségeket. A minden szemeszterben meghirdetésre kerülö kurzus célja, hogy szakmai támogatásunkkal a kar többi tanszéke is használja az oktatási folyamatban a Moodle-t, mellyel színesebbé és hatékonyabbá tehetjük a kar képzéseit. 
A rendszert az agrármérnöki, AIFSZ, BSc, MSc, PhD, Erasmus képzésekben, illetve külföldön (Románia) folyó képzésben is használjuk. Tanszékünk emellett ECDL képzésben és a NODES Projektben is kihasználja a keretrendszer funkcióit.

Miután a kari rendszer használatát kiterjesztettük a teljes Agrártudományi Centrumra 26 szakon közel 100 oktató 170 kurzussal és több mint 3000 hallgató csatlakozik az e-learning alapú oktatási folyamatba. A legtöbb kurzus az 5 új típusú alapszakon (Pénzügy és számvitel, Kereskedelem és marketing, Turizmus-vendéglátás, Gazdasági és vidékfejlesztési agrármérnök, Informatikus és szakigazgatási agrármérnök) található.

A Moodle portál látogatottsági statisztikáját a Google Analytics szolgáltatással készítem. Ennek segítségével mindig napra kész, pontos információt kapok arról hányan, honnan, milyen böngészővel, stb. használják a rendszert, mennyi időt töltenek a rendszerben. Az 1. ábra a 2009. december 14. 2010. március 31. időszak Moodle használatát mutatja.

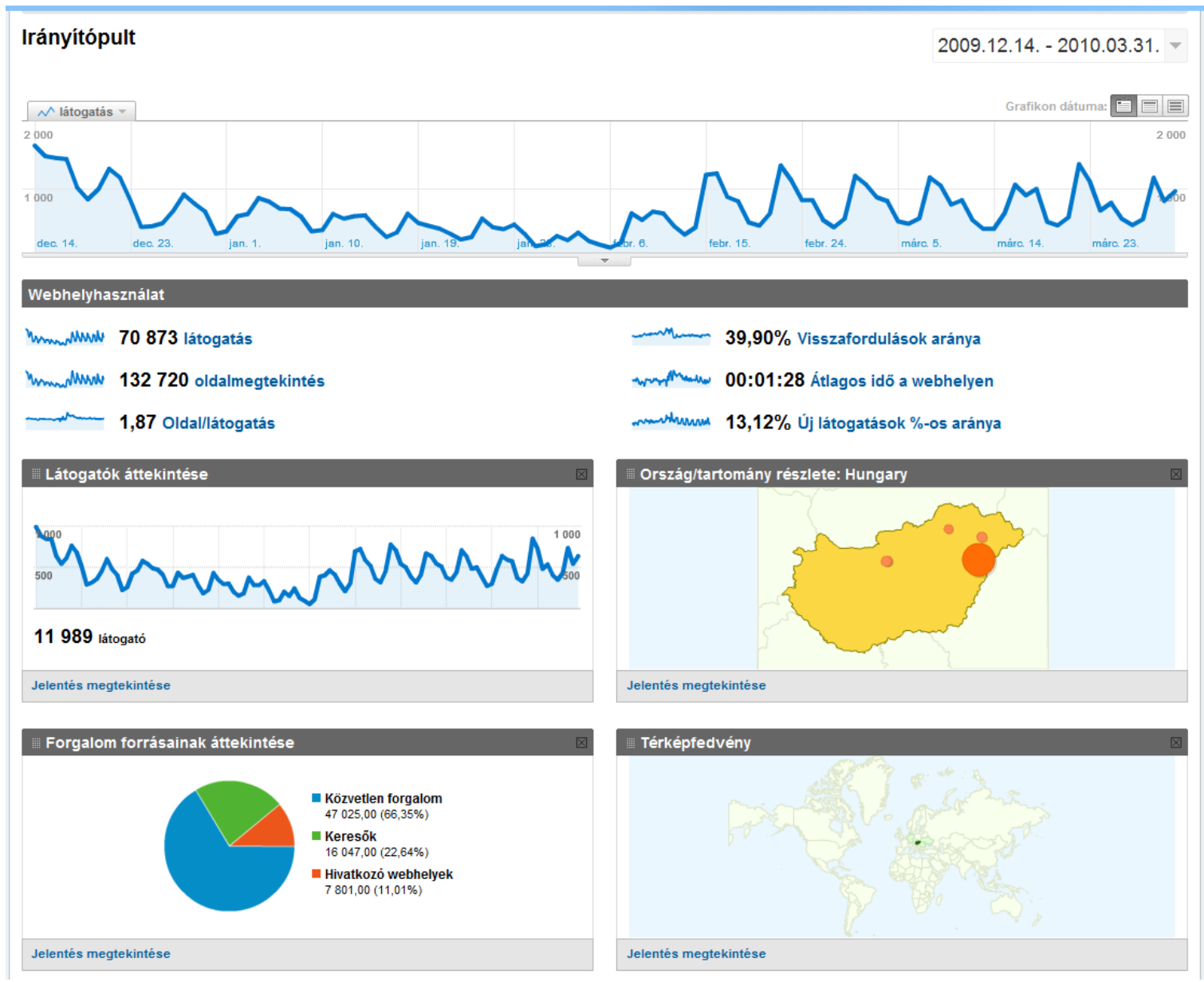

\section{1. ábra. A DE-GVK Moodle rendszerének látogatottsági statisztikája}

Forrás: Google Analytics

Ebbe az időszakba bele tartozik egy vizsgaidőszak, egy félévkezdés és a 2009/2010-es tanév II. félévének egy jelentős hányada. Az ábrán megfigyelhető, hogy a helyi maximumok hétfői napra esnek, vagyis ez az a nap, amikor a legtöbb látogatója van a rendszernek, ami hétvégére fokozatosan csökken. 


\section{E-learning portál fejlesztése}

A Moodle rendszeres és kiterjesztett használata következtében megnőtt az igény a géptermi Moodle teszteken alapuló hallgatói számonkérésekre. A géptermek tanórai kihasználása mellett biztosítanunk kellett a Moodle számonkérések kiszolgálását is. Így jött létre 2009 nyarán a Debreceni Egyetem Agrár- és Müszaki Tudományok Centrumának e-learning portálja (2. ábra). Nevéből következik, hogy ez már nem egy kari, hanem centrum szintủ portál, melyen keresztül a Moodle mellett elérhető egy online teremfoglaló rendszer, mely teljes mértékben lefedi a teremfoglalás menetét. Ezt a rendszert is a Moodle accountokkal lehet elérni, de csak oktatói jogkörrel rendelkezö felhasználók férhetnek hozzá. Ezt úgy valósítottuk meg, hogy a teremfoglaló rendszer a Moodle adatbázisát használja. Jövőbeni terveink között szerepel a Neptun rendszerrel történő integrálás is. Ennek eredményeként majd Neptun azonosítókkal lehet használni mind a Moodle, mind a teremfoglaló rendszert.

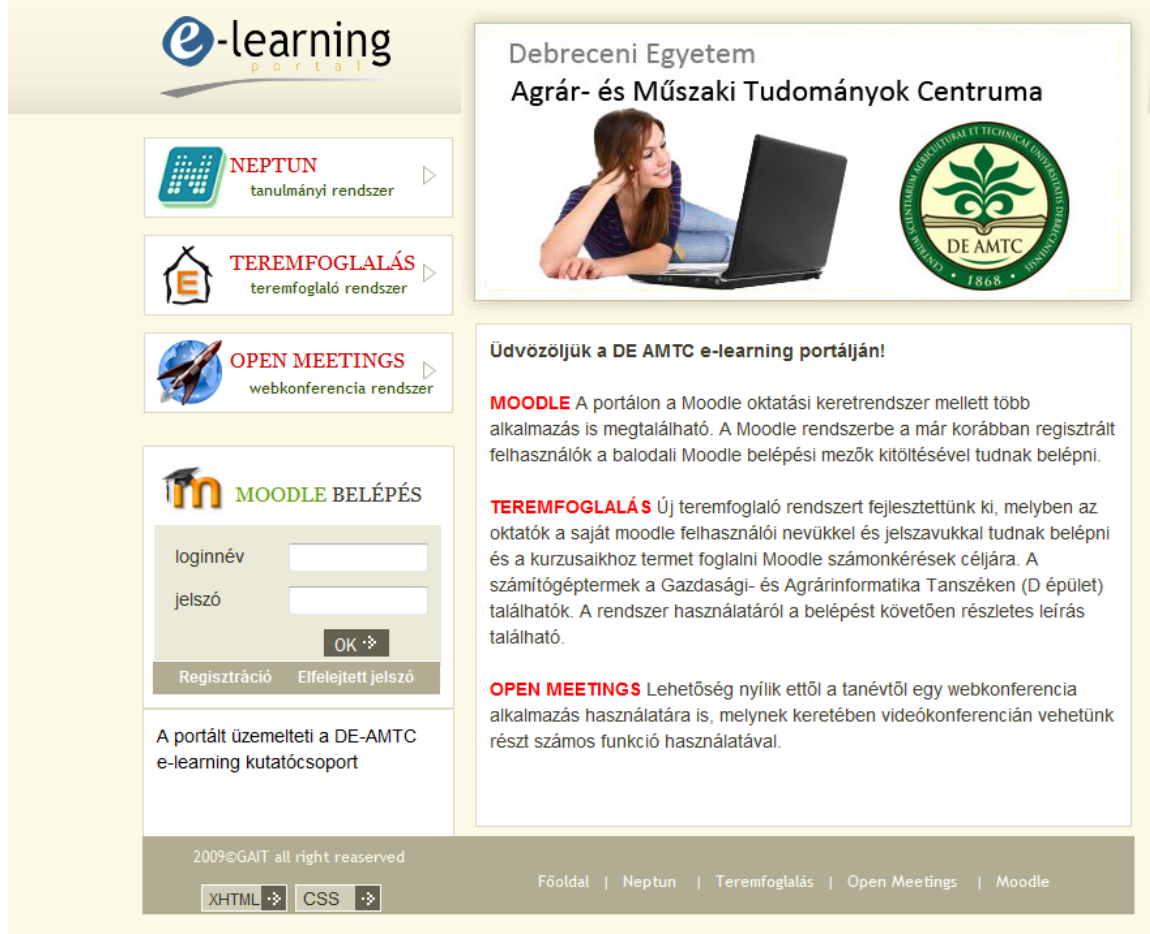

2. ábra. A DE-AMTC e-learning portáljának belépési felülete

\section{Következtetések}

Az e-learning egyre jobban hozzá tartozik az oktatási folyamatok megvalósításához, így a mindennapjainkhoz. A Debreceni Egyetem Gazdálkodástudományi és Vidékfejlesztési Karán bevezetésre került a Moodle kererendszer, ami nem jelenti azt, hogy nincs további tennivalónk az elearning technológiák használatában. A rendszer szemeszterről szemeszterre hódítja meg az oktatókat az oktatási folyamat hatékony megvalósításának eszközeként.

Ahhoz, hogy a Moodle egy jól müködő rendszer legyen, előnyeit hatékonyan ki kell használni. Ez nem történhet máshogy, csak ha nagy hangsúlyt fektetünk az oktatók folyamatos képzésére, a különböző e-learning eszközök megismerésére, alkalmazására, illetve kérdőívek segítségével kontrolláljuk a rendszert.

A hagyományos oktatást a nappali képzésben semmiképpen nem válthatja fel teljesen az online learning technológia alkalmazása, de mindenképpen nagyban segíti az oktatás hatékonyságát. A blended learning (vegyes oktatás) alkalmazása a helyes út, a képzés tartalmának és a képzési formának megfelelö arányban véve a hagyományos oktatás-tanulást, illetve az e-learning alkalmazását. 
A Moodle használata nagyban segíti karunk, centrumunk oktatóinak munkáját, és a lehetséges eszközökkel bővítve, még nagyobb lehetőség rejlik benne. Ezekkel a fejlesztésekkel és tapasztalatok gyüjtésével színvonalasabbá, hatékonyabbá tehetjük az oktatást.

\section{Irodalomjegyzék}

C. Burriel (2007): NODES - E-learning aspects and accessibility, International Conference on Agricultural Economics, Rural Development and Informatics, Debrecen, ISBN: 978-963-87118-7-8, 83-91 p.

L. Gaceu, R. Gruia, D. Danila (2009): Education In Food And Tourism Area Using Moodle Management Courses System in Transilvania University of Brasov, AVA2009 conference, Debrecen, 2009 March 26-27. pp. 548-555. (ISBN 978-963-9732-83-4)

Herdon M., Várallyai L.(2006): Multimédia forrásközpontok felnőttképzési európai e-learning hálózatának létrehozása, Networkshop 2006 Konferencia, Miskolc

M. Herdon, P. Lengyel (2008): Multimedia and e-Learning integration for supporting training programs in agriculture by Moodle, AWICTSAE2008 Workshop, Alexandroupolis, Greece

Lengyel P., Herdon M. (2008): E-learning rendszer bevezetésének tapasztalatai a Debreceni Egyetem Agrárgazdasági és Vidékfejléesztési Karán, Informatika a felsőoktatásban 2008 Konferencia, Debrecen

Lengyel P., Szilágyi R., Várallyai L. (2007): Moodle alkalmazása a Nodes e-Learning hálózatban, Multimédia az oktatásban 2007 Konferencia, Budapest

N. Manouselisa, J. Najjar, K. Kastrantasa, G. Salokheb, C. M. Stracked, E. Duval (2009): Metadata interoperability in agricultural learning repositories: An analysis, Computers and Electronics in Agriculture, ISSN: 0168-1699

Tóth T. - Aszalós L. - Nagy Z.: Minőségbiztosítási megoldások, szabványok és elvárások az informatika oktatásának területén, Informatika a felsőoktatásban 2008, Debrecen, 5 pages, ISBN: 978-963-473-129-0

Wagner E. (2008): Delivering on the promise of eLearning, Adobe Systems, White Paper 